WellBeing International

WBI Studies Repository

$6-2010$

\title{
On-Farm Welfare Assessment for Regulatory Purposes: Issues and Possible Solutions
}

\author{
Jan Tind Sørensen \\ University of Aarhus \\ David Fraser \\ University of British Columbia
}

Follow this and additional works at: https://www.wellbeingintlstudiesrepository.org/assawel

Part of the Animal Studies Commons, Other Animal Sciences Commons, and the Other Anthropology Commons

\section{Recommended Citation}

Sørensen, J. T., \& Fraser, D. (2010). On-farm welfare assessment for regulatory purposes: Issues and possible solutions. Livestock Science, 131(1), 1-7.

This material is brought to you for free and open access by WellBeing International. It has been accepted for inclusion by an authorized administrator of the WBI Studies Repository. For more information, please contact wbisr-info@wellbeingintl.org.

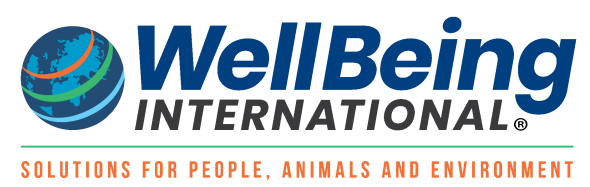




\title{
On-Farm Welfare Assessment for Regulatory Purposes: Issues and Possible Solutions
}

\author{
Jan Tind Sørensen ${ }^{1}$ and David Fraser ${ }^{2}$ \\ ${ }^{1}$ University of Aarhus \\ ${ }^{2}$ University of British Columbia
}

\begin{abstract}
KEYWORDS
on-farm welfare assessment, regulation, public perception
\end{abstract}

\begin{abstract}
On-farm welfare assessment has been used mainly for non-regulatory purposes such as producer education or to qualify for voluntary welfare-assurance programs. The application of on-farm assessments in regulatory programs would require four issues to be addressed: (1) selecting criteria that are widely accepted as valid by diverse citizens, (2) setting minimum legal levels, (3) achieving the high level of fairness and objectivity required for legally binding requirements, and (4) achieving the cost-efficiency needed for widespread use of the methods. Issues 1 and 2 pose a particular problem because different citizens disagree on what they understand as good animal welfare, with substantial differences between producers and non-producers. A solution could be a deliberative process involving panels of producers and non-producers committed to understanding the issues and reaching a deliberated solution. Issues 3 and 4 (fairness and efficiency) require scientific data on the precision, repeatability, independence, and cost-of-scoring for the various candidate criteria. A process is also needed to bring the scientific information into the deliberative process, either as formal recommendations and/or through direct participation of scientists. If these issues can be resolved, the use of on-farm assessment could in principle generate widespread acceptance, be responsive to change, and lead to better welfare outcomes than regulations that merely stipulate features of the physical environment.
\end{abstract}

\section{Introduction}

The growing global attention to farm animal welfare (Bayveld et al., 2005) has led to many different programs designed to ensure a certain level of animal welfare in food production (Fraser, 2006). Many European countries have opted to regulate production methods through legislation (Veissier et al., 2008). The response in North America has been more to create non-mandatory codes (Thompson et al., 2007), together with standards that corporate customers require of their suppliers (Brown and Hollingsworth, 2005). Other options include internationally agreed standards (OIE, 2009) and labelling programs designed to differentiate products according to welfare standards or production methods, although the extent of such programs remains limited (Martelli, 2009). 
In existing regulatory or legislative programs, many of the requirements focus on the physical environment of the animals, for example by banning certain housing systems or setting down physical requirements such as minimum space. However, evidence shows that the physical environment alone is not a good predictor of animal welfare. Genetic factors also play a major role (Sandøe et al., 1999), and human factors, including handling methods and animal care skills, can be major determinants of farm animal welfare (Hemsworth et al., 2002). Indeed, animal welfare can perhaps best be seen as the outcome of a complex interaction of the environment, management and genetics (Fraser, 2008). As a result, a given production system can give rise to very different welfare outcomes. This has been seen in loose housing systems for pregnant sows (Spoolder et al., 2009), loose housing systems for dairy cows (Whay et al., 2003a), and standard barns for intensive broiler chicken production (Dawkins et al., 2004).

Given this complexity, it is widely accepted that valid assessment of farm animal welfare requires actual on-farm assessment methods (Barnett and Hemsworth, 2009). Measures used in on-farm welfare assessment systems are often classified into resource-based measures (e.g., housing systems, space allowances, animal management practices) and animal-based measures (e.g., low-incidence of disease or injury, normal behaviour) (Main et al 2003). Animal-based measures provide more direct assessment of the state of the animals (Barnett and Hemsworth, 2009). To date on-farm welfare assessment has been used mainly for non-regulatory purposes such as producer education or in voluntary certification and labelling schemes. However if such an approach could be adapted to regulatory programs it should in principle give rise to better welfare outcomes than regulations that merely specify environmental requirements (O'Hara and O'Connor, 2007). This paper sets out issues that need to be addressed, and possible solutions, in order for on-farm welfare assessment to be used as a valid and constructive part of regulatory systems to improve the welfare of farm animals.

\section{Issue 1: Selecting widely acceptable criteria}

The application of on-farm welfare assessment to regulatory programs creates a new challenge in selecting widely acceptable criteria of animal welfare. When used only in voluntary programs, the assessment criteria can be designed to reflect specific animal welfare priorities such as high health, freedom of movement, or access to natural elements such as fresh air, and producers are then free to participate or not. In contrast, if the program is legally binding, then the assessment criteria need to be widely accepted as valid indicators of animal welfare by the citizens of the jurisdiction. However, views of animal welfare differ widely among individuals (Fraser et al., 1997), and recent research in social sciences shows particular disagreement between animal producers (farmers and ranchers who raise animals) and non-producers.

Most studies (summarized in Table 1) show that non-producers tend to emphasize freedom to live in a 'natural' manner as central to animal welfare (Te Velde et al., 2002; Vanhonacker et al., 2008). Compared to producers, non-producers seem to focus more on the ability to engage in natural behaviour (Lassen et al., 2006). For example, a recent UK study showed that $95 \%$ of the citizens did not think that keeping dairy cows indoors year-round can be associated with good animal welfare (Ellis et al., 2009). As a result of the emphasis on naturalness, non-producers often associate poor animal welfare with industrial farming (Kjaernes et al., 2007), sometimes emphasizing stocking density and pen size (Vanhonacker et al., 2009). The focus on naturalness likely explains the popularity of free range systems (Kjaernes et al., 2007) and the fact that non-producers tend to perceive animal welfare as poorer for the most intensively reared species (broilers, layers and pigs) compared to those kept less intensively (dairy cattle, beef cattle and sheep) (Maria, 2006; Heleski et al., 2004). One exception to this general picture was a study of 16 British consumers who tended to emphasize basic animal needs such as food, water, ventilation, space and light (Hall and Sandilands, 2007). 
In contrast, producers (as summarized in Table 2) tend to equate animal welfare with basic health and access to necessities such as food and water (Te Velde et al., 2002; Vanhonacker et al., 2008). An exception was farmers participating in organic or animal welfare labelling schemes who tended to equate animal welfare with freedom, comfort and the opportunity to perform natural behaviour (Bock and van Huik, 2007). Producers also tended to de-emphasize short-term pain and distress. For example, Australian beef and sheep producers emphasized stockmanship (for cattle) and parasite control (for sheep) as the most important factors for animal welfare, whereas animal welfare advocates attached the greatest importance to the painful procedures of dehorning and mulesing (Phillips et al., 2009). Moreover, producers tend to rate current animal welfare in farm animals as relatively positive (Te Velde et al, 2002; Maria, 2006; Vanhonacker et al., 2008).

Table 1. Studies on perceptions and opinions concerning farm animal welfare held by non-producers. ${ }^{1}$

\begin{tabular}{|c|c|c|c|}
\hline Reference & Welfare issue & Study methods & Conclusion \\
\hline Te Velde et al. (2002) & $\begin{array}{l}\text { Perception of treatment of } \\
\text { animals in intensive } \\
\text { animal husbandry }\end{array}$ & $\begin{array}{l}\text { Interviews with } 15 \\
\text { varied consumers } \\
\text { from the Netherlands }\end{array}$ & $\begin{array}{l}\text { - Emphasis on "freedom to move and freedom to fulfil } \\
\text { natural desires" as well as health. } \\
\text { - Consumers saw intensively raised animals as having 'a } \\
\text { short and miserable life, with lack of space, fresh air, } \\
\text { and light' }\end{array}$ \\
\hline Frewer et al. (2005) & $\begin{array}{l}\text { Attitudes toward animal } \\
\text { welfare and 'animal- } \\
\text { friendly' pig husbandry }\end{array}$ & $\begin{array}{l}\text { Questionnaire to a } \\
\text { representative } \\
\text { sample of } 500 \text { Dutch } \\
\text { consumers }\end{array}$ & $\begin{array}{l}\text { - Consumer perceptions of animal welfare could be } \\
\text { clustered under two broad headings of the animals' } \\
\text { health and their living environment }\end{array}$ \\
\hline Lassen et al. (2006) & $\begin{array}{l}\text { Perception of pig } \\
\text { production }\end{array}$ & $\begin{array}{l}\text { Interviews of six focus } \\
\text { group of } 6-7 \text { varied } \\
\text { Danish participants }\end{array}$ & $\begin{array}{l}\text { - Concern expressed over 'physical harm' (crowding, } \\
\text { injury), 'ability to follow natural instincts', and 'autonomy' } \\
\text { including 'limitations to the pig's freedom' }\end{array}$ \\
\hline Maria (2006) & $\begin{array}{l}\text { Perception of farm animal } \\
\text { welfare }\end{array}$ & $\begin{array}{l}\text { Questionnaire to } \\
3978 \text { Spanish citizens }\end{array}$ & $\begin{array}{l}\text { - Treatment of animals was felt to be better for } \\
\text { extensively reared species (sheep, cattle) than for } \\
\text { confined species (pigs, chickens) }\end{array}$ \\
\hline Kjaernes et al. (2007) & $\begin{array}{l}\text { European consumers' } \\
\text { knowledge of farm animal } \\
\text { welfare }\end{array}$ & $\begin{array}{l}\text { Qualitative analysis of } \\
\text { focus groups } 349 \\
\text { consumers from } 7 \\
\text { European countries }\end{array}$ & $\begin{array}{l}\text { - Welfare was perceived as bad in intensive production } \\
\text { systems compared to alternative systems } \\
\text { - Views were influenced by nationality and by broader } \\
\text { beliefs about nature, industry, food quality and hygiene }\end{array}$ \\
\hline $\begin{array}{l}\text { Hall and Sandilands } \\
(2007)\end{array}$ & $\begin{array}{l}\text { Attitudes toward broiler } \\
\text { chicken welfare }\end{array}$ & $\begin{array}{l}\text { Workshops with } 16 \\
\text { British consumers }\end{array}$ & $\begin{array}{l}\text { - Participants emphasized basic animal needs including } \\
\text { food, water, ventilation, space and light }\end{array}$ \\
\hline $\begin{array}{l}\text { Vanhonacker et al. } \\
\text { (2008) }\end{array}$ & $\begin{array}{l}\text { Interpretation of animal } \\
\text { welfare by citizens and } \\
\text { farmers }\end{array}$ & $\begin{array}{l}\text { Questionnaire to a } \\
\text { stratified sample of } \\
459 \text { citizens from } \\
\text { Flanders (compared } \\
\text { to farmers) }\end{array}$ & $\begin{array}{l}\text { - Citizens put more emphasis on animals' ability to } \\
\text { engage in natural behaviour, plus aspects of pain, } \\
\text { stress and space allowance } \\
\text { - Citizens evaluated animal welfare more negatively than } \\
\text { farmers }\end{array}$ \\
\hline Ellis et al. (2009) & $\begin{array}{l}\text { Perception of dairy } \\
\text { production and welfare }\end{array}$ & $\begin{array}{l}\text { Questionnaire to } 363 \\
\text { British consumers }\end{array}$ & $\begin{array}{l}\text { - Emphasis on appropriate feeding, good stockmanship, } \\
\text { space, cleanliness, and freedom } \\
\text { - Most considered it unacceptable for cows to be tethered } \\
\text { or permanently indoors }\end{array}$ \\
\hline Krystallis et al. (2009) & $\begin{array}{l}\text { Citizen attitudes toward } \\
\text { pig production systems }\end{array}$ & $\begin{array}{l}\text { Questionnaire and } \\
\text { conjoint analysis with } \\
1931 \text { citizens from } 4 \\
\text { European countries }\end{array}$ & $\begin{array}{l}\text { - Outdoor access (versus indoor housing with slatted } \\
\text { floors) and measures to protect the environment were } \\
\text { the important determinants of positive attitudes toward } \\
\text { production systems. }\end{array}$ \\
\hline
\end{tabular}

\footnotetext{
${ }^{1}$ Studies were included in the table if they identified important elements of animal welfare as perceived by non-producers.
} 
Despite these overall differences, views on animal welfare are by no means uniform within the category of either non-producers or producers. Non-producers living in rural areas (Vanhonacker et al., 2008) or raised in rural areas (Kendall et al., 2006) perceive animal welfare as more positive than non-producers in general. In a study in The Netherlands, Boogaard et al. (2006) found that people who owned a pet or lived in an urban area tended to perceive farm animals as having relatively poor quality of life, compared to people who did not own pets, lived in rural areas, or had some connection with agriculture. Societal concerns about animal welfare are usually found to be relatively high for younger people, women, and people with higher education (Maria, 2006; Vanhonacker et al., 2009), although a study in the USA found especially high levels of concern among low-income and less educated people (Kendall et al., 2006). Non-producers in general seem to have a low level of knowledge of current animal production systems (Maria, 2006; Kjaernes et al., 2007; Ellis et al., 2009). Although mass media are the most important sources of information concerning animal welfare, experience from farm visits plays an important role in laypeople's perception of farm animals and their welfare (Kjaernes et al., 2007).

Views on animal welfare may also change with people's experience. In a study involving a questionnaire to Dutch citizens on perception of farm animal welfare (Boogaard et al., 2006), a randomly selected subgroup received a leaflet with information on livestock production and farm animal welfare. The results showed that leaflet information significantly affected the image of farmers, although the perception of the current quality of life of farm animal remained the same. Producers also may change their views based on experience. As noted above, Bock and van Huik (2007) found that pig producers participating specifically in organic or animal welfare schemes resembled non-producers in emphasizing the animals' opportunity to express natural behaviour, whereas producers participating in general quality-assurance schemes defined animal welfare largely in terms of animal health and production performance. Dockès and KlingEveillard (2006) found that some French veal calf producers, after being forced to change from individual to group housing to comply with new regulations, developed greater ability to observe animals and reported a closer sense of relationship to the animals.

\subsection{Issue 1: Possible solutions}

Given the different views of animal welfare and their potential to change or vary depending on individual experience, how might consensus be reached on the welfare indicators to be included in a regulatory program? A possible means would be through a process of citizen panels including producers and nonproducers committed to a deliberative process and to being informed about farm animal production. As noted by Fearon (1998) deliberative processes provide an opportunity to share views, generate and consider a range of options, encourage options that are not simply motivated by self-interest, and to increase the legitimacy and ease of implementation of the final decision by giving all a fair say.

Given the role of knowledge in shaping beliefs about farm animal welfare, it would be important for panel members to gain experience of animal production, for example by farm visits. Citizen panels visiting dairy farms have been used successfully in the Netherlands in a study on sustainability as a socio-cultural concept (Boogaard et al., 2008). Producers should also be involved in such visits so that they experience a wide range of welfare conditions and husbandry systems.

Even if producers and non-producers differ in their philosophy of animal welfare, they may still be able to agree on a sufficient number of specific indicators for a usable welfare assessment program. Thus the goal need not to be achieve agreement on all matters but to come up with a small set of mutually agreeable indicators. Mirabito et al. (2008) describe a case study where laypeople and experts could broadly agree on animal-based measures in an on-farm welfare assessment for French cattle herds. In this study a group of laypeople were questioned on their perception of farm animal welfare and how to assess welfare on farms. Experts then structured their opinions into 15 measures, which were tested for 
precision on farms. Based on this the experts suggested 5 animal-based measures which eventually received a high degree of support from the laypeople.

Table 2. Studies on perceptions and opinions concerning farm animal welfare held by producers. ${ }^{2}$

\begin{tabular}{|c|c|c|c|}
\hline Reference & Welfare issue & Study methods & Conclusion \\
\hline Te Velde et al. (2002) & $\begin{array}{l}\text { Perception of treatment of } \\
\text { animals in intensive } \\
\text { animal husbandry }\end{array}$ & $\begin{array}{l}\text { Interviews with } 15 \\
\text { Dutch livestock } \\
\text { producers }\end{array}$ & $\begin{array}{l}\text { - Animal welfare was largely equated with good health } \\
\text { - Producers showed little awareness 'about possible } \\
\text { other aspects of animal welfare' such as 'being able to } \\
\text { display natural behaviour' } \\
\text { - Producers considered the welfare of their animals to be } \\
\text { good }\end{array}$ \\
\hline $\begin{array}{l}\text { Bock and van Huik } \\
\text { (2007) }\end{array}$ & $\begin{array}{l}\text { Attitudes and behaviour of } \\
\text { European pig farmers }\end{array}$ & $\begin{array}{l}\text { Questionnaire to } 360 \\
\text { European pig farmers } \\
\text { participating in quality } \\
\text { assurance schemes }\end{array}$ & $\begin{array}{l}\text { Producers in general quality-assurance schemes } \\
\text { equated animal welfare with basic needs (food, water, } \\
\text { climate), health and productivity } \\
\text { - Producers in organic or animal welfare schemes } \\
\text { equated animal welfare with freedom, comfort and } \\
\text { opportunity to express natural behaviour }\end{array}$ \\
\hline $\begin{array}{l}\text { Vanhonacker et al. } \\
\text { (2008) }\end{array}$ & $\begin{array}{l}\text { Interpretation of animal } \\
\text { welfare by citizens and } \\
\text { farmers }\end{array}$ & $\begin{array}{l}\text { Questionnaire to } 204 \\
\text { farmers from } \\
\text { Flanders (compared } \\
\text { to citizens) }\end{array}$ & $\begin{array}{l}\text { - Farmers considered feed and water, animal health, and } \\
\text { human-animal relations the most important aspects of } \\
\text { animal welfare } \\
\text { - Farmers judged current animal welfare as positive }\end{array}$ \\
\hline Phillips et al. (2009) & $\begin{array}{l}\text { Relative importance of } \\
\text { practices affecting welfare } \\
\text { of beef cattle, sheep and } \\
\text { goats }\end{array}$ & $\begin{array}{l}\text { Questionnaire to } 278 \\
\text { Australian animal } \\
\text { industry workers } \\
\text { compared to animal } \\
\text { welfare advocates }\end{array}$ & $\begin{array}{l}\text { - Farmers attached greatest important to stockmanship } \\
\text { (cattle) and parasite control (sheep) } \\
\text { - Animal welfare advocates attached greatest importance } \\
\text { to painful procedures: dehorning (cattle) and mulesing } \\
\text { (sheep) }\end{array}$ \\
\hline
\end{tabular}

${ }^{1}$ Studies were included in the table if they identified important elements of animal welfare as perceived by non-producers.

\section{Issue 2: Setting minimum acceptable levels of animal welfare}

In existing on-farm assessment programs, the various measures are often aggregated in some manner to produce an overall score (Bartussek, 1999; Whay et al., 2003b; Botreau et al., 2007a,b) or even a simple verbal summation that may be used for farm advisory support (Bonde et al., 2001). However, if assessments are used for regulatory purposes, they will generally need to make a clear discrimination between acceptable and unacceptable operations. Thus, in addition to identifying the measures to be used, a regulatory program would also require minimum acceptable standards to be set. The challenge will be to identify criteria of acceptability that will cover the main concerns of non-producers while also being recognized by producers as providing valid criteria of unacceptable practice.

\subsection{Issue 2: Possible solutions}

Here again, a process of deliberation involving producers and non-producers shows promise as a means of achieving a workable result. In New Zealand, for example, an on-farm welfare assessment scheme for pigs was developed using such a model (Barugh et al., 2009). Indicators, which were scored by a 'trafficlight' system of green, amber and red, were selected in consultation with interested parties including pig producers, pig veterinarians and members of an animal protection organization. Similarly, in Canada a code of practice for care and handling of dairy cattle (DFC, 2009), developed by producers, regulators, veterinarians, scientists and the humane movement, agreed on a number of required minimum criteria such as the use of pain management during disbudding of calves. 
Operations may be judged unacceptable for two types of reasons: either because they involve unacceptable practices, or because they fail to meet minimum standards for quantitative measures. For example the slaughter-plant audit of the American Meat Institute (Grandin, 2001) identifies certain practices as unacceptable (dragging any conscious animal, beginning slaughter procedure on any animal that shows signs of sensibility) and sets minimum acceptable levels for variables such as the percentage of animals rendered unconscious by the first attempt at stunning.

The two types of criteria require somewhat different approaches. Identifying unacceptable practices is a form of ethical decision-making simply requiring agreement on what should be allowed. In many cases controversial practices (long-term restriction of movement, painful procedures done without pain management) have become flash-points for criticism of industries, and they figure prominently among the concerns of non-producers. A process of communication and negotiation might allow producers to better appreciate the level of damage done to their industry by such practices, and hence cause producers to be agreeable to reform. In many cases, for example, production companies or producer associations have decided unilaterally to abandon certain practices because they recognized the damage that they cause. Thus some companies have decided to phase out gestation stalls for sows, and the United Egg Producers decided to eliminate the controversial practice of forced moulting of hens by feed restriction (UEP, 2008).

In contrast, setting minimum levels for quantitative measures will often require data collection to establish what levels are achieved on farms judged to provide acceptable welfare. For example in the American Meat Institute audit mentioned above, setting the standard for stunning efficacy in cattle (i.e., that 95\% of animals must be stunned correctly on the first attempt) began with surveys of the levels commonly achieved in well managed plants (Grandin, 2006).

\section{Issue 3: The need for fairness and to avoid false failures}

If on-farm animal welfare assessment methods are used for regulatory purposes there is a particular need for fairness and consistency such that different auditors, suitably trained but likely having different level of experience of animal production, will arrive at the same judgement. There is also a need to avoid 'false failures'. Failing the assessment of a voluntary labelling program merely excludes producers from one avenue for marketing, but failing an assessment used for regulatory purposes could potentially force producers to give up their livelihood. Hence, false failures need to be avoided, both for fairness and for the credibility of the system.

\subsection{Issue 3: Possible solutions}

Careful training of auditors will obviously be needed. In addition, however, the identification of objective and relevant measures is largely a scientific task that needs to involve research on repeatability and precision of scoring. Such information needs to be included in the process of selecting the ultimate measures. For example, in developing the Welfare Quality assessment protocol for dairy cattle, the duration for lying down and rising for dairy cows were investigated as behavioural indicators of resting behaviour in 35 dairy farms (Hesse et al., 2006). Interobserver reliability for lying down and rising was consistently high in all test sessions. However, given the consistency over time in the behaviour plus the limited amount of time available for on-farm welfare assessment, only duration of lying down was recommended for the monitoring system. Although animal-based measures were preferred in the Welfare Quality assessment protocols, resource-based measures were chosen in some cases. For example in choosing an indicator for thirst, dehydration (detected by the skin pinch test) was not considered to be sensitive enough in normal farm conditions. Therefore assessment is done by analysing the resources available to the animals such as number of water troughs (Botreau et al., 2009). 
Especially in the early stages, it will also be important to monitor failures carefully to ensure that farms with good overall welfare do not fail for minor or inappropriate reasons, and to create a procedure for appeal and re-assessment.

\section{Issue 4: Efficiency}

As long as on-farm assessment methods are used for voluntary purposes such as labelling or product differentiation programs, there is no compelling need for the assessment methods to be cost-efficient. If used for regulatory purposes, however, assessments may need to be applied to a large number of farms by public-sector officials, and the methods will almost certainly need to be efficient in time and cost.

\subsection{Issue 4: Possible solution}

To be efficient, an assessment program would need to include only a small number of criteria which should be strong indicators of the standard of welfare on the farm. The problem is essentially a scientific one in two respects.

First, of the many candidate measures, some may be duplicative in the sense of merely indicating the same features. Hence, statistical analysis needs to be applied to identify a small number of measures which are relatively independent of each other but which together have high power of discriminating acceptable from unacceptable operations. An example is given by Scott et al. (2001) who suggest the development of composite animal welfare scales by using statistical methods (such as cluster analysis) to reduce a large number of candidate indicators to a small number with little loss of information.

Second, different measures differ widely in the time required for them to be scored. For example in a welfare assessment on organic layers, replacing clinical examination of a sample of 50 hens with a plumage condition score applied to the flock would reduce the total time needed by an inspector by $30 \%$ (Sørensen et al., 2007). Such cost-efficiency considerations need to be included in decisions about the measures to be selected.

In addition, self-inspection procedures for some indicators may be a way to improve efficiency of on-farm welfare assessment as long as this can be done without reducing the credibility of the program.

\section{Discussion}

Incorporating on-farm welfare assessment into regulatory programs would require a combination of social and scientific validity.

Social validity, in this case, means that the program must be seen as a valid indication of acceptable animal welfare from the viewpoint of the citizens of the jurisdiction, including both producers and nonproducers. Our proposed solution - formal groups of producers and non-producers committed to understanding the issues and to achieving a deliberated outcome - has many parallels in the resolution of other complex issues. Public participation through citizen juries and panels is applied to priority-setting for health care in many countries (Mitton et al., 2009), and 'community' members often participate with scientists to assess the acceptability of proposed research using animals (Schuppli and Fraser, 2005). In Sweden, for example, seven local ethics committees, including equal numbers of scientists and nonscientists, examine applications for animal experiments (Ideland, 2009).

Given the large differences between producers and non-producers in their views on animal welfare, a process of discussion and negotiation could have multiple benefits. Many producers have little opportunity to fully understand the concerns of non-producers. Moreover, publications that criticize modern animal 
production often provide very inaccurate accounts of production practices (Fraser, 2001). Perhaps as a result, many producers appear to believe that public concerns are merely due to misinformation, and that concerns could be eliminated by 'educating' the public. In fact, common concerns of non-producers - for example about untreated pain and the unnatural nature of confinement housing - reflect a longstanding current in Western thought that values the natural ahead of the technological and emphasizes sympathy and emotion (Fraser, 2008). A deliberative process might allow producers to better appreciate the nature and depth of public concerns and the damage done to their industries by practices that offend against deeply rooted values. The experiences from this communication might also be useful to guide education programs for farmers.

Similarly, a deliberative process might allow non-producers to understand the validity of producers' concerns, especially over basic animal health. Non-producers tend to have little personal exposure to animal production (Martelli, 2009), and in emphasizing naturalness as central to animal welfare, they may overlook the basic health issues that are important aspects of animal welfare. Exposure to producers and farms might make non-producers more willing to respect the concerns of producers as well as their own.

Scientific information would be important in the design of the program for several purposes: to propose proven measures for different aspects of animal welfare, to determine repeatability and efficiency of scoring different measures, and to determine which combinations of measures provide relatively independent rather than duplicative information.

Two different models have been used to bring scientific input into deliberation over standards. In the 'participatory' model, used in drafting most farm animal welfare codes in Canada before 2006, scientists participated as 'stakeholders', sitting along with producers and non-producers as part of the committee that drafted the standards. Although this ensures that scientific expertise is available during the drafting, it does not ensure that all relevant science is considered, as there is no formal process for assembling the relevant literature. Moreover, scientists may feel compromised if serving on a committee that rejects science-based recommendations for economic or other reasons. In contrast, the 'advisory' model, used by the United Egg Producers in the USA (Bell et al., 2004) and in drafting a revised dairy code in Canada (Bradley and MacRae, 2010), begins with a committee of scientists who make a formal review of the literature and recommend standards and criteria based solely on the science. Then a stakeholder committee adopts, rejects or modifies the scientists' recommendations after considering such factors as feasibility and economic impact. The advisory model has the advantages of providing a formal process for ensuring that all relevant science is considered, as well as a clearer separation between the scientific and non-scientific elements of the final decisions.

A deliberative process that takes both producer and non-producer values into account may lead to better animal welfare outcomes than some of the means of reform used to date. If a negotiated system is not available to respond to public concerns, then the public may instead seek to influence farm animal welfare in less nuanced ways, for example by calling for simple bans on certain types of physical facilities. Such decisions risk causing unintended or undesired outcomes. If a jurisdiction bans a housing system that is valued by producers, then production may simply move to other jurisdictions. For example, after the citizens of Switzerland voted to ban the use of cages for egg production in 1981, Swiss egg production declined (from about $42 \mathrm{t}$ in 1981 to about $36 \mathrm{t}$ in 1991) while imports, presumably from countries where cages were still used, increased by a similar amount (FAO, 2009). Especially in cases where a particular housing system originally helped solve certain welfare problems, banning the system could cause a return of those problems unless the ban is combined with additional measures. Caged systems for egg production helped to eliminate poultry red mite, and the parasite appears to be returning as non-cage systems are being more widely used in advance of the European Union ban on standard cages (Höglund et al., 1995). In an epidemiological study in Denmark, mortality rates in non-cage 
systems $(8.6 \%, 12.1 \%$ and $17.1 \%$, in free range, deep litter and organic systems respectively) were substantially higher than in cage-based production (5.4\%), suggesting that the non-cage systems in the study had unresolved problems of basic bird health, even though they would comply with a legal ban on cages (von Borell and Sørensen, 2004). A regulatory system based on actual on-farm welfare assessment and agreed by producers and non-producers could in principle lead to welfare improvements without these unintended and undesirable consequences.

Experience suggests that in many cases, producers are opposed to regulatory approaches to farm animal welfare (Fraser, 2006). However, if provisions are negotiated rather than simply imposed, producers might prove supportive. Experience in other professions shows the advantages of having a means to eliminate unacceptable practices and standards. Professions such as medicine have developed standards of acceptable practice and a means of disciplining practitioners who fail to meet these standards, and the result is a high level of public trust in the profession. Animal producers, in contrast, may be aware of bad practices and low-welfare farms that discredit their industry, but lack a mechanism to rectify the problem. Hence progressive producers may welcome a clear means of distinguishing acceptable from unacceptable operations as long as these are based on criteria that the producers themselves consider valid.

In this paper we have focused on adapting welfare assessment to regulatory programs, but the same approach - involving deliberative panels of producers and non-producers combined with structured scientific advice - could also be applied to other problems such as standards at slaughter plants, corporate purchasing policies, and labelling programs for product differentiation.

\section{References}

Barnett, J.L., Hemsworth, P.H., 2009. Welfare monitoring schemes: using research to safeguard welfare of animals on the farm. J. Appl. Anim. Welf. Sci. 12, 114-131.

Bartussek, H., 1999. A review of the animal needs index (ANI) for the assessment of animals' well-being in the housing systems for Austrian proprietary products and legislation. Livest. Prod. Sci. 61, 179-192.

Bayveld, A.C.D., Rahman, S.A., Gavinelli, A., 2005. Animal welfare: global issues, trends and challenges. Rev. Sci. Tech., Off. Int. Epiz., vol. 24.

Barugh, I., Mellor, D., Neumann, E., Vink, D., 2009. A tool for on-farm welfare assessment of pigs in New Zealand. J. Appl. Anim. Welf. Sci. 12, 145-146.

Bell, D., Chase, B., Douglass, A., Hester, P., Mench, J., Newberry, R., Shea-Moore, M., Stanker, L., Swanson, J., Armstrong, J., 2004. UEP uses scientific approach in its establishment of welfare guidelines. Feedstuffs 76 (11), 1-9.

Bock, B.B., van Huik, M.M., 2007. Animal welfare: the attitudes and behaviour of European pig farmers. Brit. Food J. 109, 931-944.

Bonde, M., Rousing, T., Sørensen, J.T., 2001. Structure of the welfare assessment report for communication with farmers. Acta Agric. Scand. Sect A. Animal Sci. Suppl. 30, 58-61.

Boogaard, B.K., Oosting, S.J., Bock, B.B., 2006. Elements of societal perception of farm animal welfare: a quantitative study in The Netherlands. Livest. Sci. 104, 13-22.

Boogaard, B.K., Oosting, S.J., Bock, B.B., 2008. Defining sustainability as a socio-cultural concept: citizen panels visiting dairy farms in the Netherlands. Livest. Sci. 117, 24-33. 
von Borell, E., Sørensen, J.T., 2004. Organic livestock production in Europe: aims, rules and trends with special emphasis on animal health and welfare. Livest. Prod. Sci. 90, 3-9.

Botreau, R., Bonde, M., Butterworth, A., Perny, P., Bracke, M.B.M., Capdeville, J., Veissier, I., 2007a. Aggregation of measures to produce an overall assessment of animal welfare. Part 1: A review of existing methods. Animal 1, 1179-1187.

Botreau, R., Bracke, M.B.M., Perny, P., Butterworth, A., Capdeville, J., Van Reenen, C.G., Veissier, I., 2007b. Aggregation of measures to produce an overall assessment of animal welfare. Part 2: Analysis of constraints. Animal 1, 1188-1197.

Botreau, R., Bonde, M., Buller, H., Butterworth, A., Evans, A., Forkman, B., Keeling, L., Van Reenen, K., Veissier, I., Velarde, A., Winckler, C., 2009. Scenarios for farm visits. Deliverable D2.36 and D2.37, WP2.5. EU Food-CT-2004-506-508.

Bradley, A., MacRae, R., 2010. Legitimacy \& Canadian farm animal welfare standards development: the case of the National Farm Animal Care Council. J. Agric. Environ. Ethics, doi:10.1007/s10806-010-9240z.

Brown, K.H., Hollingsworth, J., 2005. The Food Marketing Institute and the National Council of Chain Restaurants: animal welfare and the retail food industry in the United States of America. Rev. Sci. Tech. Off. Int. Epiz. 24, 655-663.

Dawkins, M.S., Donnelly, C.A., Jones, T.A., 2004. Chicken welfare is influenced more by housing conditions than by stocking density. Nature 427, 342-344.

DFC, 2009. Code of practice for the care and handling of dairy cattle. Dairy Farmers of Canada (DFC) and the National Farm Animal Care Council, Ottawa. Available at www.dairygoodness.ca, accessed October 2009.

Dockès, A.C., Kling-Eveillard, F., 2006. Farmers' and advisers' representations of animals and animal welfare Livest. Sci. 103, 243-249.

Ellis, K.A., Billington, K., McNeil, B., McKeegan, D.E.F., 2009. Public opinion on UK milk marketing and dairy cow welfare. Anim. Welf. 18, 267-282.

FAO, 2009. FAOSTAT. www.Faostat.fao.org, accessed September 2009.

Fearon, J.D., 1998. Deliberation as discussion. In: Elster, J. (Ed.), Deliberative Democracy. Cambridge University Press, Cambridge, pp. 44-68.

Fraser, D., Weary, D.M., Pajor, E.A., Milligan, B.N., 1997. A scientific conception of animal welfare that reflects ethical concerns. Anim. Welf. 6, 187-205.

Fraser, D., 2001. The "New Perception" of animal agriculture: legless cows, featherless chickens, and a need for genuine analysis. J.Anim. Sci. 79, 634-641.

Fraser, D., 2006. Animal welfare assurance programmes in food production: a framework for assessing the option. Anim. Welf. 15, 93-104.

Fraser, D., 2008. Understanding animal welfare. The science in its cultural context. Wiley-Blackwell, Oxford. 
Frewer, L.J., Kole, A., van der Kroon, A.M.A., De Lauwere, C., 2005. Consumer attitude towards the development of animal friendly husbandry systems. J. Agric. Environ. Ethics 18, 345-367.

Grandin, T., 2001. Cattle slaughter audit form (updated October 2001), based on American Meat Institute Guidelines. Available at: http://www.grandin.com/cattle.audit.form.html, consulted October 2009.

Grandin, T., 2006. Progress and challenges in animal handling and slaughter in the U.S. Appl. Anim. Behav. Sci. 100, 129-139.

Hall, C., Sandilands, V., 2007. Public attitudes to the welfare of broiler chickens. Anim. Welf. 16, 499512.

Heleski, C.R., Mertig, A.G., Zanella, A.J., 2004. Assessing attitudes towards farm animal welfare: a national survey of animal science faculty members. J. Anim. Sci. 82, 2806-2814.

Hemsworth, P.H., Coleman, G.J., Barnett, J.L., Borg, S., Dowling, S., 2002. The effects of cognitive behavioral intervention on the attitude and behavior of stockpersons and the behavior and productivity of commercial dairy cows. J. Anim. Sci. 80, 68-78.

Hesse, N., Knierim, U., Laister, S., Winckler, C., Zucca, D., Minero, M., 2006. Reliability testing concerning behaviour around resting in cattle. Deliverable D2.10.14, EU Food-CT-2004 14, 506-508.

Höglund, J., Nordenfors, H., Uggla, A., 1995. Prevalence of the poultry red mite, Dermanyssus gallinae, in different types of production systems for egg layers in Sweden. Poult. Sci. 74, 1793-1798.

Ideland, M., 2009. Different views on ethics: how animal ethics is situated in a committee culture. J. Med. Ethics 35, 258-261.

Kendall, H.A., Lohan, L.M., Sharp, J.S., 2006. Public concern with animal wellbeing: place, social structural location and individual experience. Rural Sociol. 71, 399-428.

Kjaernes, U., Miele, M., Roex, J., 2007. Attitudes of consumers, retailers and producers to farm animal welfare. Welfare Quality Report number 2. Cardiff University, Cardiff.

Krystallis,A., Barcellos, M.D.,Kügler, J.O.,Verbeke,W., Grunert, K.G., 2009. Attitudes of European citizens towards pig production systems. Livest. Sci. 126, 46-56.

Lassen, J., Sandøe, P., Forkman, B., 2006. Happy pigs are dirty! Conflicting perspectives on animal welfare. Livest. Sci. 103, 221-230.

Main, D.C.J., Kent, J.P., Wemelsfelder, F., Ofner, E., Tuittens, F.A.M., 2003. Applications for methods of on-farm assessment. Anim.Welf. 12, 445-456.

Maria, M., 2006. Public perception of farm animal welfare in Spain. Livest. Sci. 103, 250-258.

Martelli, G., 2009. Consumers perception of farm animal welfare: an Italian and European perspective. Ital. J. Anim. Sci. 8, 31-41 Suppl. 1.

Mirabito, L., Capdeville, J., Dockès, A.C., Kling, F., Brule, A., 2008. Assessment of cattle welfare on farms: an example of cooperation with consumers. Books of abstract. 4th int. workshop on anim. welf. assess at farm or group level, 10-13 Sept. 2008, Ghent, p. 61. 
Mitton, C., Smith, N., Peacock, S., Evoyd, B., Abelson, J., 2009. Public participation in health care priority setting: a scoping review. Health Policy 91, 219-228.

O'Hara, P.O., O'Connor, C., 2007. Challenge of developing regulations for production animals that produce the welfare outcomes we want. J. Vet. Behav. 2, 205-212.

OIE, 2009. Terrestrial animal health code. World Organisation for Animal Health (OIE), Paris.

Phillips, C.J.C., Wojciechowska, J., Meng, J., Cross, N., 2009. Perceptions of the importance of different welfare issues in livestock production. Animal 3, 1152-1166.

Sandøe, P., Nielsen, B.L., Christensen, L.G., Sørensen, P., 1999. Staying good while playing god — the ethics of breeding farm animals. Anim. Welf. 8, 313-328.

Scott, E.M., Nolan, A.M., Fitzpatrick, J.L., 2001. Conceptual and methodological issues related to welfare assessment: a framework for measurement. Acta Agric. Scand., Section A. Anim. Sci. 30, 5-11.

Schuppli, C.A., Fraser, D., 2005. The interpretation and application of the Three Rs by Animal Ethics Committee members. Alternatives Lab. Anim. 33, 487-500.

Sørensen, J.T., Rousing, T., Møller, S.H., Bonde, M.K., Hegelund, L., 2007. On-farm welfare assessment systems: what are the recording costs? Anim. Welf. 16, 237-239.

Spoolder, H.A.M., Geudeke, M.J., Van der Peet-Schwering, C.M.C., Soede, N.M., 2009. Group housing of sows in early pregnancy: a review of success and risk factors. Livest. Sci. 125, 1-14.

Te Velde, H.T., Aarts, N., Van Woerkum, C., 2002. Dealing with ambivalence: farmers' and consumers' perceptions of animal welfare in livestock breeding. J. Agric. Environ. Ethics 15, 203-219.

Thompson, P., Harris, C., Holt, D., Pajor, E.A., 2007. Livestock welfare product claims: the emerging social context. J. Anim. Sci. 85, 2354-2360.

UEP, 2008.United Egg Producer's animal husbandry guidelines for U.S. egg laying flocks, 2008 Edition. United Egg Producers (UEP), Alpharetta, GA. Available at: www.uepcertified.com, accessed October 2009.

Vanhonacker, F., Verbeke, W., Van Poucke, E., Tuyttens, F., 2008. Do citizens and farmers interpret the concept of farm animal welfare differently? Livest. Sci. 122, 126-136.

Vanhonacker, F., Verbeke, W., Van Poucke, E., Buijs, S., Tuyttens, F.A.M., 2009. Societal concern related to stocking density, pen size and group size in farm animal production. Livest. Sci. 123, 16-22.

Veissier, I., Butterworth, A., Bock, B., Roe, E., 2008. European approach to ensure good animal welfare. Appl. Anim. Behav. Sci. 113, 279-297.

Whay, H.R., Main, D.C.J., Green, L.E., Webster, A.J.F., 2003a. Assessment of the welfare of dairy cattle using animal-based measurements: direct observations and investigation of farm records. Vet. Rec. 153, 197-202.

Whay, H.R., Main, D.C.J., Green, L.E., Webster, A.J.F., 2003b. An animal based welfare assessment of group housed calves on UK dairy farms. Anim. Welf. 12, 611-617. 